\title{
Creating a Learner-Centered Communicative Classroom to Help Learners Achieve Optimal Outcome
}

\author{
Yanying $\mathrm{Yu}^{1, \mathrm{a}}$, Yichen Liu ${ }^{2, \mathrm{~b}}$ \\ ${ }^{1}$ Xian Shiyou University, Xi'an, Shannxi Province, P. R China \\ ${ }^{2}$ Xian Shiyou University, Xi'an, Shannxi Province, P. R China \\ ayyyu@xsyu.edu.cn, b317170264@qq.com
}

Keywords: English teaching; learner-centered; topic-based; communicative classroom

\begin{abstract}
This paper mainly introduces an effective learner-centered communicative (LCC) classroom in teaching Oral Presentation (OP) to the English minors in the Foreign Language School of Xi'an Shiyou University. Details of the course, class activities, and strategies in oral presentation are discussed and illustrated. LCC classroom turns out to be practical and effective in improving the students' ability both in their oral and in their written expressions in English.
\end{abstract}

\section{Introduction}

With the development of science and technology, the globe is getting smaller. People are communicating more than ever before in this "global village" [3]. As English is widely used in the world, there is an increasing need for some more effective approaches in ELT presently in order to improve the learners' ability of communication in English.

Thus, communicative language teaching, initiating from late 1970s and early 1980s, has been widely adopted in ELT.

\section{Communicative Language Teaching}

Richards, Platt and Platt [9] define Communicative Language Teaching (CLT) or communicative approach as "an approach to foreign or second language teaching which emphasizes that the goal of language learning is communicative competence....”

Conventionally, the learners' language ability is often considered a two-way process: input and output. Input includes reading and listening while output consists of speaking and writing. Mastery of these language skills, however, cannot guarantee that a learner knows how to use a language in the proper social context. "Someone knowing a language knows more than how to understand, speak, read and write sentences. He also knows how sentences are used to communicative effect" [11]. This is what Hymes [7] called "communicative competence".

In a communicative classroom, real-life communication is the focus and the learners' language ability is the main concern. "Learner-centered" is the slogan to a communicative classroom in which a teacher plays a facilitative role and the learner initiative is emphasized.

\section{A Learner-Centered Communicative (LCC) Classroom}

"Learner-centered" is a feature of a communicative classroom. With the development of communicative teaching in ELT, teachers grow more interests in the individual learners' needs, interests, motivation and learning styles. In the teaching practice, we can always see that some learners are more successful than others are. These successful learners have some features in common: They are highly motivated; they have clear goals; they show more interests to new things and they create their learning strategies. But "A characteristic of highly successful learners is that they are autonomous" [4]. Since the mid-70s of the $20^{\text {th }}$ century, to promote the students' autonomy has been emphasized, "ELT has come to espouse principles of learner-centered teaching" [7].

Grunert [6] defines that "a learning-centered approach to college education asks you to consider 
how each and every aspect of your course can most effectively support students learning." According to Weatherholtz [10], in a learner-centered classroom, learners learn to assess their own work and participate in the assessment of their counterparts' work, which leads them to be self-directed.

Students' autonomy is “the ability to take charge of one's own learning” [5]. Therefore, a learner-centered classroom should focus on the individual learners. The teacher's task in a learner-centered classroom is mainly to facilitate the students to "initiate the planning and implementation of their own learning program” [2].

From the discussion above, we can see that a learner-centered communicative classroom enables the learner to be autonomous and self-directed, highly motivated, and more interested in learning and using the language in authentic linguistic settings.

A variety of classroom activities can be adopted in a communicative classroom. Different types of activities serve for different content of the course to help the learners develop different language skills. Generally, interactive activities are proposed to help the learners develop their vocabulary, grammar and language skills actively in a communicative way.

\section{A Case Study of LCC Classroom}

A learner-centered curriculum should "set out to provide learners with efficient learning strategies, to assist them in identifying their own preferred ways of learning. They should also help learners to develop skills needed to negotiate the curriculum, to set their own objectives, to adapt realistic goals and time frames, and to develop their own skills in self-evaluation”[8].

The Foreign Language School of Xi'an Shiyou University offers English Minors Program for students majoring in science and technology who have passed CET-4 or CET-6 (College English Test --- Band 4 and Band 6). The aim of the program is to help the students improve their English language ability comprehensively. Therefore, different courses are designed to match the aim. Among the courses is the OP (Oral Presentation).

As the teacher offering OP course to the English minors, I have worked out a learner-centered communicative classroom for the students.

\subsection{Overview of the course}

\section{Length of the course:}

\section{Learners:}

Aims of the course:

social contexts

Type of syllabus:

Course materials:
18 weeks, 4 hours per week

Total hour: 72 hours

Students majoring in science and technology

(CET-4 or CET-6 certificate holders)

Improving the students' ability in using oral English in various

As can be seen from the overview of the course, the main purpose of the course is to help the students improve their oral ability in using English communicatively. Therefore, a topic-based syllabus is adopted in the instruction.

Topic-based or theme-based instruction "provides an alternative to what would otherwise be traditional language classes by structuring a course around themes or topics. Theme-based curricula can serve the multiple interests of students in a classroom and can offer a focus on content while still adhering to institutional needs for offering a language course per se” [1].

As the students are all CET-4 or CET-6 certificate holders, their English is of intermediate or advanced levels. Most of them have a vocabulary of more than 4000 words, and they are good "readers" in English. There is no Course Book for this OP class, but the teacher may provide some in-house materials relating to the topics dealt with during the class.

Some popular topics suggested by the students and adopted in the class include Self-introduction (name, age, education, interests and hobbies ...), Family Life, Learning English, Future Career, The 
Weather, Foods and Drinks, Sports and Music, Traveling, Making Friends, Smoking and Drinking, Computer and Internet, Medical Care, Environment, Population, Terrorism...

\subsection{Arrangement of class activities}

\section{Step 1: Providing the topic: Questions and Answers}

At the beginning of the class, the teacher will write a topic on the blackboard, for example, self-introduction. Then the teacher will ask some questions for the students to think of. For the topic of "self-introduction", the teacher will ask:

1. Would you like to introduce yourself?

2. What information do you want to include in your self-introduction?

The students may give different answers to the questions. As they are "shouting" out their answers, the teacher can write them on the blackboard while responding orally to the students:

\section{Student A: Name}

Student B: Age

Teacher: Yes, your name and age.

Student C: Education background

Teacher: OK, educational background...

Student D: Hometown and family

Teacher: That's right.

Student E: Our hobbies and interests

Teacher: Good! Hobbies and interests!

(Write what the students mention on the blackboard.)

(Recorded in the OP classroom, March 21, 2012)

\section{Step 2: Group Discussion}

When they stop their voice in answering the questions, the students will be divided into groups of three or four to have a discussion about the topic. In the discussion, they are required to ask each other questions around the topic. They are suggested to use different sentence structures to ask a question. For example:

Student A: Would you please introduce yourself to us?

Student B: Yes, er...my name is $* * *$ and I major in petroleum engineering.

Student C: Excuse me. Can you tell us how old you are?

Student B: Yeah, I'm 21 this year and ... and I was born in Sichuan Province.

Student D: Do you have any brothers or sisters?

Student B: Oh, no. I am sorry not. I'm the only child in the family. And you? Do you have a brother or a sister?

Student D: I have a sister, an elder sister.

(The discussion continues.)

(Recorded in the OP classroom, May 8, 2015)

As the students have their discussions, the teacher goes around and listens to their conversations and provides necessary help they need in vocabulary and expressions. However, the teacher is not supposed to point out the students' errors so often, for this will hinder them from expressing fluently. Too much error correction will make the students lose confidence and courage in oral communication.

\section{Step 3: Presentation}

After an intense discussion on the topic, the students will be asked to have a presentation in front of the class based on their discussion. The teacher will comment on the students' presentation and talk more about the strategies used in talking about the topic. Some of the common errors in the students' presentation can be discussed during the class so that every student will benefit from it.

\subsection{Strategies in oral presentation}

In talking about things, the teacher can divide the topics into groups according to the strategies 
used, and provide them with necessary structures and vocabulary, so that the speakers can adopt different strategies to give their opinions. For example:

Providing information or facts: self-introduction, family, education ...

Giving opinions: population, pollution, drinking and smoking, terrorism ...

Making suggestions: learning English, making friends, finding a job ...

Here is an example:

Teacher: Let's see how we can give our opinions. Taking "Drinking and Smoking” as an example, we often say that every coin has two sides...

How can you talk about things with two sides?

Student A: A general description of the topic first.

Teacher: OK, a general description of the topic.

Student B: A topic sentence indicating the benefits, then listing the benefits.

Student C: We can also give examples.

Student D: ...

(The teacher writes what the students suggest.)

(Recorded in the OP classroom, June 5, 2015)

When talking about such topics as "Drinking and Smoking", the teacher can ask the students to have a debate. When talking about "Sports and Music", some English songs and video programs can be shown to the students. All these class activities are designed to arouse the students' further interests in the topic.

\subsection{Outcome of the Course}

In such a learner-centered communicative classroom, the English minors are highly motivated and greatly interested in the class activities. "It is a challenge, for we have to search for the proper ways to communicate in English. We have learnt English for many years and most of us have large vocabulary. We can recognize the words in reading, but we cannot recall them when we need them in real oral communication". "Now I feel confident in communicating with native speakers. I can express myself with more words and appropriate ways". These words from the same students in the interviews at the beginning and the end of the course are evidence of the success of the learner-centered communicative instruction.

\section{Conclusions}

The English Minors Program has been running for 18 years in Xi'an Shiyou University. It satisfies the needs of the "Talent Market" in China. As a result, the English minors either continued their study as postgraduates or found "satisfying" jobs after graduation. A large number of them are working overseas successfully because they can COMMUNICATE well in English --- the lingua franca in the world.

\section{References}

[1] Brown, H.D. Teaching by Principles: An Interactive approach to Language Pedagogy. New York: Addison Wesley, 2001.

[2] Brumfit, C.J. and Johnson, K. The Communicative Approach to Language Teaching. New York: Oxford University Press, 1979.

[3] Burns, A. and Coffin, C. Eds. Analyzing English in a Global Context. London: Routledge, 2001.

[4] Davies, P and Pearse, E. Success in English Teaching. Oxford: Oxford University Press, 2000.

[5] Gardner, D. and Miller, L. Establishing Self-Access: From Theory to Practice. Cambridge: Cambridge University Press, 1999. 
[6] Grunert, J. The Course Syllabus: A Learning-Centered Approach. Bolton, MA: Anchor Publishing, 1997.

[7] Hymes, D.H. “On Communicative Competence”. In J. B. Pride and J. Holmes (eds.) Sociolinguistics. Harmondsworth: Penguin Books, 1972.

[8] Nunan, D. The Learner-Centered Curriculum. Cambridge: Cambridge University Press, 1988

[9] Richards, J.C., Platt, J. and Platt, H. 2000. Longman Dictionary of Language Teaching and Applied Linguistics. Beijing: Foreign Language Teaching and Research Press, 1988.

[10] Weatherholtz, D. Learner-Centered Teaching: Five Key Changes to Practice---Book Review. San Francisco: Jossey-Bass, 2003.

[11]Widdowson, H.G. Teaching Language as Communication. New York: Oxford University Press, 1978. 